\title{
Efficacy of Mineral Oil-Insecticide Mixtures for Protection of Potato Tubers Against PVY and PVM
}

\author{
Sławomir Wróbel \\ Published online: 25 June 2014 \\ (C) The Author(s) 2014. This article is published with open access at Springerlink.com
}

\begin{abstract}
The impact of a dozen mixtures of the most commonly applied aphicides: Mospilan 20 SP (acetamiprid), Pirimor 500 (pirimicarb) and Karate Zeon 050 CS (lambdacyhalothrin), combined with the mineral oil Sunspray 850 EC, was researched in field conditions to assess their effectiveness in limiting potato tuber PVY, PVM and PLRV infection. In spite of the greatest reduction in the number of aphids occurring following application of Mospilan $20 \mathrm{SP}$, this treatment was not as effective in limiting PVY infection as, for example, applying Sunspray 850 EC mineral oil. Mineral oil, when used on its own or in a mixture with Pirimor $500 \mathrm{WG}$, was found to be the most effective measure for limiting PVY infection (the incidence of tubers infested with PVY was reduced by $64 \%$ relative to control, i.e. no protection). A slightly weaker effect was observed in the case of a combination of the mineral oil with full doses of Karate Zeon $050 \mathrm{CS}$ with a half of a dose of Mospilan 20 SP insecticide, however only for protection against PVY. A similar trend was observed for PVM even though a significant difference was only observed for Sunspray 850EC+Pirimor 500WG. In conclusion, the application of insecticide mixtures with mineral oil in protecting against PVY infection is not always as effective as the application of the oil itself only. Addition of the insecticide may sometimes improve the efficacy of protection, however, due to the extra costs involved, not always does it have to be economical.
\end{abstract}

Resumen Bajo condiciones de campo, se investigó el impacto de una docena de mezclas de los siguientes aficidas más comúnmente aplicados: Mospilan 20 SP (acetamiprid),

\section{S. Wróbel $(\square)$}

Department of Potato Protection and Seed Science in Bonin, Plant Breeding and Acclimatization Institute - National Research Institute, 76-009 Bonin, Poland

e-mail: wrobel@ziemniak-bonin.pl
Pirimor 500 (pirimicarb) y Karate Zeon 050 CS (lambdacyhalothrin), combinados con el aceite mineral Sunspray $850 \mathrm{EC}$, para evaluar su efectividad en limitar la infección de tubérculo por PVY, PVM y PLRV. A pesar de la mayor reducción en el número de áfidos que se presentaron después de la aplicación de Mospilan 20 SP, este tratamiento no fue tan efectivo en limitar la infección de PVY como, por ejemplo, con la aplicación del aceite mineral Sunspray 850 EC. El aceite mineral, al usarlo solo o en mezcla con Pirimor 500 WG, se encontró que era la medida más efectiva para limitar la infección de PVY (la incidencia de tubérculos infectados con PVY se redujo en un $64 \%$ con respecto al testigo sin protección). Se observó un efecto ligeramente más débil en el caso de la combinación del aceite mineral con dosis completa de Karate Zeon 050 CS con la mitad de la dosis del insecticida Mospilan 20 SP, aunque fuera solamente para protección contra PVY. Se observó una tendencia similar para PVM, aun cuando se observó diferencia significativa solamente para Sunspray 850EC+ pirimor 500 WG. En conclusión, la aplicación de mezclas de insecticidas con aceite mineral en la protección contra la infección de PVY no es siempre tan efectiva como la aplicación únicamente del aceite solo. La adición del insecticida puede mejorar algunas veces la eficacia de la protección, no obstante, debido al costo extra involucrado, no siempre tiene que ser económica.

Keywords Acetamiprid · Pirimicarb · Lambda-cyhalotrin · Mineral oil $\cdot$ PVY $\cdot$ PVM

\section{Introduction}

The potato is susceptible to numerous diseases, including viral infections. Viruses are considered to be among the most dangerous and difficult diseases to control. According to Brunt et al. (1997) the potato can be attacked by over 50 
viruses. However, not all of them are of economic importance. The most significant are: Potato virus Y (PVY), Potato virus M (PVM) and Potato leafroll virus (PLRV). These can substantially lower the quantity and quality of the yield (Kerlan 2009, Rahman et al. 2010, Whitworth et al. 2006), and because of potatoes' vegetative way of reproduction, they are easily transmitted to new generations of tubers. These viruses are widespread across Europe, while PVY is a very common virus in many regions of the world (Solomon-Blackburn and Barker 2001) with over 350 plant species as potential hosts (Shukla et al. 1994). PVM is a widespread potato virus found more commonly in Eastern Europe than in other parts of the world (Loebenstein and Thottappilly 2003), although it is also common in New Zealand (Fletcher 2012). It does not have such economic significance as PVY except in cases of infection of cultivars strongly reacting to PVY infection (Chrzanowska and Zagórska 1996). In some parts of the world, PLRV is still perceived to be the virus that causes the greatest volume of losses in tuber yield after PVY, reaching up to $90 \%$ (Kerlan 2009, Rahman and Akanda 2010). However, due to a limited number of potential hosts - approximately 40 species (Sharma 2006, Thomas and Hassan 2002) - and limited vectors, as well as commonly applied insecticides, it has a substantially reduced impact.

Both viruses PVY and PVM are transmitted by aphids in a non-persistent manner on their stylets (Kostiw 1987, Basky 2003). Many aphid species have the ability to transmit viruses on stylets. However potato colonizing aphids are the most effective vectors. Myzus persicae Sulzer is the most effective PVY vector (Cerato et al. 1994, Collar et al. 1997, Derron and Goy 1990, Kostiw 1987, Sigvald 1984). Aphis nasturtii Kalt. is the most effective vector of PVM (Kostiw 1987) due to its widespread presence in potato plantations and can play a role in the spread of PVY as well (Kostiw 2011). Aphids flying over potato plantations by chance in search for an host plant, yet are not potato colonizing aphids, play an increasingly important role in non-persistent transmission during the initial phase of the growth season (Kostiw and Robak 2008, 2010). This is associated with their earlier (approx. 2 weeks) and more intense flights than potato aphids in Poland. Some of these are able to transmit viruses in a non-persistent manner (Sigvald 1984, Kostiw 1987, Kostiw and Robak 2002). PLRV is also transmitted by aphids but in a persistent manner. Having acquired the virus an aphid becomes its vector for the rest of its life. M. persicae is the most effective vector (Robert and Maury 1970, Robert 1971, Kostiw 1987, Castle and Berger 1993).

Virus diseases are particularly significant in seed production where virus protection is a priority. Chemical control of virus vectors is one approach adopted for controlling the spread of these. Though, in the case of protection against PLRV, chemical treatment is effective, for PVY and PVM it is of little or no benefit at all (Milošević 1996, Iovieno et al.
2002, Olubayo et al. 2010, Hansen and Nielsen 2012). When sources of PVY and PVM infection are found on the plantation or nearby, aphid control itself is not effective because of the short duration an aphid requires to acquire and transmit the virus from one plant to another (already from a few seconds) compared to the much greater time required to paralyze the aphid following its treatment with an insecticide (Kostiw 1987, Wróbel and Turska 2007). When a potato plantation is adequately isolated from sources of infection, effectiveness of insecticides in limiting the spread of the virus can reach high levels because of the small probability of its transmission (Wisłocka and Gabriel 1980, Milošević et al. 2012).

The application of mineral oil is a more effective way of protecting against non-persistent viruses. Studies implying the possibility of oil substance usage in protection against viruses were reported as early as the 1960s, in particular against PVY (Bradley et al. 1962, 1966; Bradley 1963). Nowadays mineral oils are commonly applied for potato protection in many European countries (Harringrton et al. 1989, Sigvald and Hulle 2004, Martín-López et al. 2006, Ameline et al. 2010, Steinger et al. 2014), including in Poland, where it is used increasingly in the case of cultivars susceptible to PVY. A high level of effectiveness (over $50 \%$ ) for potato protection against PVY infection was reported in field conditions by Kurppa and Hassai (1989), Milošević (1996), Turska and Wróbel (1999), Wróbel (2006), Rolot et al. (2008), Boiteau et al. (2009), Olubayo et al. (2010), Fageria et al. (2014), Steinger et al. (2014). According to Boiteau et al. (2009), in addition to application of mineral oil, greater protection can be achieved by ensuring adequate isolation around the plantation, e.g. use of potato plants resistant to PVY. However, Steinger et al. (2014) stated that the efficacy of mineral oil treatment was higher in the years of high infection pressure or for the most susceptible potato cultivars. In earlier studies it was demonstrated that some oil substances, apart from offering PVY protection can also protect potatoes from PVM (Kostiw and Iskrzycka 1976) and Potato virus S (PVS) as well as against PLRV (Turska 1984).

Therefore, the question arises whether one can apply in a single treatment a mixture of insecticide and oil and what effect this then has in providing protection against viruses? Moreover, whether the addition of oil, which is a type of adjuvant, allows one to decrease the dose of the insecticide without losing its effectiveness? Many studies have previously described the possibility of applying mineral oils together with insecticides in the protection of various plants against viruses (Lowery et al. 1990, Marco 1993, Weeb and Stephen 1993, Asjes 1991). In the case of potatoes, much of the research has been based on using out-of-date and often no longer available pyrethroids (Bell 1989, Gibson and Rice 1986, Rolot et al. 2008) or on comparing the effectiveness of protection against viruses between oils and insecticides or mixtures of insecticides only (Martín-López et al. 2006, van 
Toor et al. 2009, Olubayo et al. 2010). Many papers are concerned exclusively with the impact of the mineral oil or insecticides on aphids themselves, their development or ability to acquire viruses (Powell and Hardie 1994, Powell et al. 1998, Ameline et al. 2010, Martoub et al. 2010, Boquel et al. 2013).

Thus, in order to investigate the above questions, the current research, carried out in field conditions during the period 2008-2011, assessed the impact of seven mixtures of the most frequently applied aphicides: Mospilan 20 SP, Pirimor 500 WG and Karate Zeon 050 CS with mineral oil Sunspray 850 EC to analyze their effectiveness in limiting the infection of potato tubers by PVY, PVM and PLRV.

\section{Material and Methods}

The research was carried out in field conditions in 2008, 2009 and 2011 in the north of Poland in the Department of Seed Production and Potato Protection of the Institute of Plant Acclimatization and Production at the National Research Institute at Bonin near Koszalin. The effectiveness of seven mixtures of the mineral oil Sunspray 850 EC with three commonly applied insecticides was assessed in terms of efficacy of potato tuber protection against viruses. The following insecticides were applied: Mospilan 20 SP, Pirimor 500 WG and Karate Zeon 050 CS using full and half doses of these substances (Table 1).

To assess the effectiveness of the mineral oil, insecticides and their mixtures in limiting the infection of potato tuber with PVY, PVM and PLRV, we used an early cultivar, Rosalind, which is susceptible to viruses (resistance to PVY - 5.5; PVM3.5; PLRV - 6 using a resistance scale of 1-9 where 1 denotes no resistance and 9-extreme resistance). Every year healthy seed material of the elite class (B/I or B/II) was supplied by the owner of the cultivar, the Europlant company.

The experiment involved three replications in each year with full randomization of the experimental plots. Each plot had 100 potato plants ( 25 plants per row x 4 rows, each plant planted in an area of $0.75 \mathrm{~m} \mathrm{x} 0.3 \mathrm{~m}$ ). Additionally, around each field, 50 potato plants which were secondarily PVY, PVM, and PLRV infected were planted and these constituted the source of infection. This arrangement was intended to create provocative conditions by increasing virus pressure.
Table 2 Index of combinations and number of treatments in research years

\begin{tabular}{lllll}
\hline No. & Combination & 2008 & 2009 & 2011 \\
\hline 1. & Control (without protection) & - & - & - \\
2. & Karate Zeon 050 CS & 9 & 8 & 7 \\
3. & Pirimor 500 WG & 9 & 4 & 5 \\
4. & Mospilan 20 SP & 5 & 4 & 3 \\
5. & Sunspray 850 EC & 10 & 8 & 7 \\
6. & Sunspray+50 \% Karate & $10 / 9^{\dagger}$ & $8 / 8^{\dagger}$ & $7 / 7^{\dagger}$ \\
7. & Sunspray+Karate & $10 / 9$ & $8 / 8$ & $7 / 7$ \\
8. & Sunspray+50 \% Pirimor & $10 / 9$ & $8 / 4$ & $7 / 5$ \\
9. & Sunspray+Pirimor & $10 / 9$ & $8 / 4$ & $7 / 5$ \\
10. & 50 \% Sunspray+50 \% Mospilan & $10 / 5$ & $8 / 4$ & $7 / 3$ \\
11. & Sunspray+50 \% Mospilan & $10 / 5$ & $8 / 4$ & $7 / 3$ \\
12. & Sunspray+Mospilan & $10 / 5$ & $8 / 4$ & $7 / 3$ \\
\hline
\end{tabular}

$\dagger$ In the case of mixtures, the first value denotes the number of treatments with mineral oil exclusively. The second value denotes the number of treatments in which a mixture of oil and insecticide was used

The whole experimental plot had potatoes planted on its three sides, which measured over 100 meters; on the fourth side, about 15 meters away there was a field with winter barley planted on it. Between this field and the experimental plot there was a stretch of fallow land.

The observations of the number of aphids on potatoes were carried out every 10 days, starting from 1 June. The method of 100 leaves was applied. For this purpose one leaf was picked from the middle layers from each plant (100 leaves in total) and all the aphids were counted, sorted according to species and developmental forms. The aphids were counted in order to determine a threshold above which you need to spray insecticide. Because $99 \%$ of the observed aphids were non-winged it was straightforward to assess the dynamics of aphids' development which provided information on the effectiveness of the treatment. The observation was finished at the end of July.

Treatments with mineral oil were conducted systematically every 7 days (its recommended frequency) and the number of treatments using the insecticides dependent on the number of aphids in earlier observations. If the number recorded during observations was small (i.e. the number did not increase) only the oil was used, otherwise an adequate amount of insecticide was added (Table 2). The first treatment was made having arrived at $95 \%$ of emergence in the plots (end of May, beginning
Table 1 Mineral oil and insecticides applied in the experiment

\begin{tabular}{|c|c|c|c|c|}
\hline Brand name & Producer & $\begin{array}{l}\text { Active ingredient - } \\
\text { amount in } 1 \text { liter/kilogram }\end{array}$ & Effect on plant & Dose \\
\hline Sunspray 850 EC & Sunoco & mineral oil $-850 \mathrm{~g}$ & contact & $151 \mathrm{ha}^{-1}$ \\
\hline Karate Zeon 050 CS & Syngenta Limited & lambda-cyhalothrin - $50 \mathrm{~g}$ & contact & $0.151 \mathrm{ha}^{-1}$ \\
\hline Pirimor $500 \mathrm{WG}$ & Syngenta Limited & pirimicarb $-500 \mathrm{~g}$ & systemic & $0.5 \mathrm{~kg} \mathrm{ha}^{-1}$ \\
\hline Mospilan $20 \mathrm{SP}$ & Nippon Soda Co Ltd & acetamiprid $-200 \mathrm{~g}$ & systemic & $0.15 \mathrm{~kg} \mathrm{ha}^{-1}$ \\
\hline
\end{tabular}


of June) and the last one at the end of July. The treatments were carried out using a small sprayer tractor using a hollow-cone nozzles (disc number $1.0 \mathrm{~mm}$ ) at a pressure of approx. 8 bar.

A week after the last treatment with mineral oil, leaves were destroyed chemically-mechanically. For this purpose, the above ground part of the plant was broken down using a tractor haulm smasher topper, leaving behind an approximately $15 \mathrm{~cm}$-long stalk which was subsequently sprayed with a half dose of Reglone 200 SL (active ingredient - diquat ion $200 \mathrm{~g} \mathrm{l}^{-1}$ ), i.e. $2.51 \mathrm{ha}^{-1}$.

To assess the effectiveness of the protection against viruses, one tuber of diameter $40-50 \mathrm{~mm}$ was taken from each plant at random, a total of $3 \times 100$ tubers for each combination. The assessment of PVY, PVM and PLRV infection of the collected tubers was carried out following 8-9 months of storage, in the spring of the following year (April-May) in a visual examination using the DAS ELISA test. The assessment procedure was as follows: having removed a part of the tuber with an eye, these were planted in pots with soil substrate in a glasshouse. Approximately 4 weeks after planting, rising 2-3 leaves were picked out from the middle layer of each plant and juice was extracted from them. The juice was diluted with a buffer (ratio 1:10) and the presence of viruses (PVY, PVM and PLRV) was assessed applying the modified DAS ELISA test procedure, as described by Wróbel (2013). Polyclonal antibodies by Neogen Europe Ltd. (http://plant.neogeneurope.com) were applied, along with titer micro plates by Greiner Bio (No. 655101).

The results on the virus infection of tubers were transformed for normality of data taking a constant inoculum (the number of infectors around the plot) according to the equation (Wójcik et al. 1976):

$y=\log \left[100 \ln \left(1-\frac{\text { value in } \%}{100}\right)^{-1}\right]+1$

in which

y value after transformation

value in $\%$ values of virus infection in percentage

Subsequently the obtained results were analyzed using an analysis of variance (ANOVA). To assess the significance of differences between the studied combinations and years, mean values were tested using Tukey's test at the significance level $\alpha=0.05$. Statistical calculations were made using Statistica program 10.0 (StatSoft, Inc. 2011). Following the analyses, the obtained values were retransformed into percentage values and are presented in this form in the paper.

\section{Results and Discussion}

The spreading of viruses between years was varied (Table 3, 4). The findings indicate that the greatest pressure of viruses
Table 3 The effectiveness of different protection systems against PVY in particular years of research (percentage of infected tubers, \pm SD standard deviation)

\begin{tabular}{lllllll}
\hline Group of treatments & 2008 & & 2009 & & 2011 & \\
\hline Control & $40.2 \pm 8.2$ & a & $10.9 \pm 4.2$ & a & $17.2 \pm 7.3$ & a \\
Insecticides & $26.8 \pm 11.7$ & ab & $11.6 \pm 4.2$ & a & $9.8 \pm 3.0$ & ab \\
Mineral oil & $12.6 \pm 4.0$ & c & $5.0 \pm 0.0$ & b & $6.1 \pm 1.0$ & b \\
Mineral oil+insecticides & $19.1 \pm 6.7$ & bc & $10.0 \pm 4.0$ & a & $5.3 \pm 2.4$ & b \\
Mean & $20.5 \mathrm{a}$ & & $9.4 \mathrm{~b}$ & & $6.6 \mathrm{c}$ & \\
\hline
\end{tabular}

means within each column with the same letters do not differ significantly according to the Tukey test $(\alpha=0.05)$

was recorded in 2008, and the lowest in 2011. For PLRV, in spite of there being many sources of this virus at each of the plots, there was no observable spreading.

Kostiw (2011) also highlights the dominating role of PVY in Poland's conditions claiming that, since 2006, the first infections with this virus have been observed to appear cyclically very early, i.e. as soon as the last 10 days of May. This is in contrast to previous years when they were not as repetitive and took place at different times, starting between the last week of May until the second half of June. In the case of PVM, the situation is very similar.

According to Chrzanowska et al. (2011) the dominating significance of PVY in Poland is connected with changes in the population of strains of this virus and the susceptibility of some cultivars to Potato Tuber Necrotic Ringspot Disease (PTNRD), caused by necrotic strain PVY ${ }^{\mathrm{NTN}}$ (Chrzanowska 2004, Chrzanowska and Zagórska 2004), as well as an increase in the importance of other aphid species as virus vectors (Kostiw and Robak 2008), weather changes (earlier spring, warm and dry periods in the summer), and lower resistance of cultivated cultivars (especially foreign ones). PVM occurs nowadays with a much smaller intensity than observed 30 years ago (Zagórska and Chrzanowska 2007). Whereas PLRV, on the basis of a 12-year period of observations (Kostiw 2011) and detailed data from the official control of

Table 4 The effectiveness of different protection systems against PVM in particular years of research (percentage of infected tubers, $\pm \mathrm{SD}$ standard deviation)

\begin{tabular}{lllllll}
\hline Group of treatments & 2008 & & 2009 & & 2011 & \\
\hline Control & $9.5 \pm 1.8$ & a & $0.3 \pm 0.6$ & a & $0.3 \pm 0.6$ & a \\
Insecticides & $8.6 \pm 2.6$ & a & $1.8 \pm 1.2$ & a & $2.0 \pm 1.8$ & a \\
Mineral oil & $4.6 \pm 6.0$ & a & $0.6 \pm 0.6$ & a & $1.0 \pm 1.6$ & a \\
Mineral oil+insecticides & $5.4 \pm 4.2$ & a & $0.9 \pm 1.0$ & a & $1.6 \pm 1.4$ & a \\
Mean & $5.6 \mathrm{a}$ & & $0.9 \mathrm{~b}$ & & $1.2 \mathrm{~b}$ &
\end{tabular}

means within each column with the same letters do not differ significantly according to the Tukey test $(\alpha=0.05)$ 
Table 5 Incidence of PVY infected tubers [\%] in particular years of research in the tested protection combinations $( \pm \mathrm{SD}-$ standard deviation)

means within each column with the same letters do not differ significantly according to the Tukey test $(\alpha=0.05)$

\begin{tabular}{llllllll}
\hline Combination & 2008 & & 2009 & & 2011 \\
\hline Control & $40.2 \pm 8.2$ & a & $10.9 \pm 4.2$ & ab & $17.2 \pm 7.3$ & a \\
Karate Zeon 050 CS & $33.0 \pm 10.8$ & ab & $16.5 \pm 1.0$ & a & $8.8 \pm 3.7$ & abc \\
Pirimor 500 WG & $19.6 \pm 15.2$ & ab & $9.7 \pm 3.3$ & ab & $12.0 \pm 2.7$ & ab \\
Mospilan 20 SP & $24.7 \pm 9.9$ & ab & $8.2 \pm 2.0$ & ab & $8.0 \pm 1.2$ & abc \\
Sunspray 850 EC & $12.6 \pm 4.0$ & $\mathrm{~b}$ & $5.0 \pm 0.0$ & $\mathrm{~b}$ & $6.1 \pm 1.0$ & $\mathrm{bcd}$ \\
Sunspray 850 EC+50 \% Karate Zeon 050 CS & $18.8 \pm 3.2$ & $\mathrm{ab}$ & $15.1 \pm 4.9$ & $\mathrm{a}$ & $5.9 \pm 1.7$ & $\mathrm{bcd}$ \\
Sunspray 850 EC+Karate Zeon 050 CS & $25.7 \pm 1.9$ & $\mathrm{ab}$ & $8.5 \pm 3.9$ & $\mathrm{ab}$ & $2.2 \pm 1.2$ & $\mathrm{~d}$ \\
Sunspray 850 EC+50 \% Pirimor 500 WG & $12.3 \pm 13.2$ & $\mathrm{~b}$ & $9.9 \pm 3.0$ & $\mathrm{ab}$ & $8.1 \pm 1.4$ & $\mathrm{abc}$ \\
Sunspray 850 EC+Pirimor 500 WG & $13.3 \pm 3.3$ & $\mathrm{ab}$ & $6.2 \pm 3.1$ & $\mathrm{ab}$ & $3.5 \pm 2.4$ & $\mathrm{~cd}$ \\
50\% Sunspray 850 EC+50 \% Mospilan 20 SP & $24.5 \pm 2.7$ & $\mathrm{ab}$ & $10.7 \pm 2.7$ & $\mathrm{ab}$ & $4.9 \pm 3.3$ & $\mathrm{bcd}$ \\
Sunspray 850 EC+50 \% Mospilan 20 SP & $13.5 \pm 0.6$ & $\mathrm{ab}$ & $8.2 \pm 4.1$ & $\mathrm{ab}$ & $4.9 \pm 1.7$ & $\mathrm{bcd}$ \\
Sunspray 850 EC+Mospilan 20 SP & $22.4 \pm 2.0$ & $\mathrm{ab}$ & $8.6 \pm 3.4$ & $\mathrm{ab}$ & $6.6 \pm 0.6$ & $\mathrm{abcd}$ \\
\hline
\end{tabular}

seed material (Wróbel and Wasik 2013), its low pressure in Poland was recorded, or with a total absence in some regions of the country. This implies that a virus which used to be considered to be the most dangerous 20-30 years ago, causing huge yield losses, at present has no significance at all.

Mineral oil was most effective in protection against PVY (Table 3). In comparison with insecticide protection the differences were clear and statistically significant in each year of the research, in spite of varied infection pressure of the virus. Similar dependencies were observed also for PVM, yet they were not statistically significant (Table 4). In practice, according to Milošević et al. (2012) if there is a high pressure of PVY, using only insecticides to control it, is impossible. Also Hansen and Nielsen (2012) did not find any significant impact of neonicotinoids in PVY control, in spite of their high efficacy in controlling the number of aphids. It is the mineral oil which many researchers in particular Olubayo et al. (2010), Hansen and Nielsen (2012), Fageria et al. (2014), Steinger et al. (2014)), consider to be the most efficient in protecting potatoes against PVY

Using insecticides on their own as well as in mixtures with mineral oil does not always impact upon control of aphid numbers (Wróbel 2011b). However, the reduction of the number of aphids in a situation where around healthy material there are numerous sources of infection (plants infected with viruses) does not guarantee protection of healthy plants against the infection (Milošević et al. 2012). This can be confirmed by Mospilan 20 SP.

Used much less often than other insecticides, it has nevertheless been found to offer the greatest effectiveness for aphid control (Wróbel 2011b). Yet in assessing its effectiveness in limiting PVY infection, it was not as effective as Sunspray mineral oil 850 EC (Table 5). It was found that Sunspray 850 EC mineral oil used by itself or together with Pirimor $500 \mathrm{WG}$ limited the PVY infection very effectively (the incidence of PVY infested tubers was lowered by $64 \%$ compared to the
Table 6 Incidence of PVM infected tubers [\%] in particular research years for tested protective combinations ( \pm SD standard deviation)

means within each column with the same letters do not differ significantly according to the Tukey test $(\alpha=0.05)$

\begin{tabular}{lllllll}
\hline Combination & 2008 & & 2009 & & 2011 \\
\hline Control & $9.5 \pm 1.8$ & $\mathrm{a}$ & $0.3 \pm 0.6$ & $\mathrm{a}$ & $0.3 \pm 0.6$ & $\mathrm{a}$ \\
Karate Zeon 050 CS & $11.5 \pm 0.6$ & $\mathrm{a}$ & $1.5 \pm 2.0$ & $\mathrm{a}$ & $1.8 \pm 3.2$ & $\mathrm{a}$ \\
Pirimor 500 WG & $6.3 \pm 1.8$ & $\mathrm{a}$ & $2.0 \pm 0.9$ & $\mathrm{a}$ & $1.5 \pm 1.1$ & $\mathrm{a}$ \\
Mospilan 20 SP & $7.8 \pm 2.1$ & $\mathrm{a}$ & $1.5 \pm 1.2$ & $\mathrm{a}$ & $2.0 \pm 0.9$ & $\mathrm{a}$ \\
Sunspray 850 EC & $4.6 \pm 6.0$ & $\mathrm{ab}$ & $0.6 \pm 0.6$ & $\mathrm{a}$ & $1.0 \pm 1.6$ & $\mathrm{a}$ \\
Sunspray 850 EC+50 \% Karate Zeon 050 CS & $5.1 \pm 2.5$ & $\mathrm{a}$ & $1.0 \pm 0.1$ & $\mathrm{a}$ & $2.0 \pm 0.0$ & $\mathrm{a}$ \\
Sunspray 850 EC+Karate Zeon 050 CS & $4.5 \pm 3.0$ & $\mathrm{ab}$ & $1.0 \pm 0.1$ & $\mathrm{a}$ & $2.1 \pm 1.5$ & $\mathrm{a}$ \\
Sunspray 850 EC+50 \% Pirimor 500 WG & $9.1 \pm 6.7$ & $\mathrm{a}$ & $0.4 \pm 1.2$ & $\mathrm{a}$ & $1.1 \pm 1.7$ & $\mathrm{a}$ \\
Sunspray 850 EC+Pirimor 500 WG & $0.6 \pm 0.6$ & $\mathrm{~b}$ & $0.0 \pm 0.0$ & $\mathrm{a}$ & $0.3 \pm 0.6$ & $\mathrm{a}$ \\
50 \% Sunspray 850 EC+50 \% Mospilan 20 SP & $5.1 \pm 2.5$ & $\mathrm{a}$ & $1.1 \pm 2.0$ & $\mathrm{a}$ & $1.5 \pm 2.0$ & $\mathrm{a}$ \\
Sunspray 850 EC+50 \% Mospilan 20 SP & $7.5 \pm 4.7$ & $\mathrm{a}$ & $1.7 \pm 0.6$ & $\mathrm{a}$ & $2.8 \pm 1.3$ & $\mathrm{a}$ \\
Sunspray 850 EC+Mospilan 20 SP & $4.2 \pm 1.6$ & $\mathrm{ab}$ & $0.6 \pm 0.6$ & $\mathrm{a}$ & $0.3 \pm 0.6$ & $\mathrm{a}$
\end{tabular}


unprotected control). A slightly weaker effect was observed in the case of a mixture of mineral oil with full doses of Karate Zeon $050 \mathrm{CS}$ or with half a dose of insecticide Mospilan 20 SP but only for PVY protection. This is an interesting result, as in spite of the frequent usage (weekly) of Karate Zeon $050 \mathrm{CS}$ - the insecticide producing a contact-based effect both on its own and in mixture with the mineral oil - there were no significant differences in reducing the number of aphids during the growth season (Wróbel 2011b). The effectiveness of the remaining combinations of the insecticide with mineral oil, or insecticideonly treatments, was too small, compared to oil only, to be practically useful.

Many authors point to better penetration and higher effectiveness of the insecticide when applied in combination with the mineral oil, as compared to when used on its own (Moustafa and El-Attal 1985; Horowitz et al. 1997), yet this dependency is not always replicated for all insecticides (Treacy et al. 1991; Pree et al. 1996). Martin-López et al. (2006) claim that in spite of the absence of any reduction of aphids numbers on potatoes, mineral oil was much more effective in reducing the level of PVY tuber infection than cypermethrin, following the usage of which, 4 times fewer aphids were recorded. Therefore, it is not always the case that the reduction of aphid numbers on leaves results in a lower level of tuber infection by viruses.

The impact of the assessed insecticides, applied in various combinations, for the reduction of PVM spread was statistically significant only in one year of the research and the differences were much smaller than in the case of PVY (Table 6).

One reason for this could have been the much lower and quite diversified pressure of this virus in the research years. Moreover, from previous research it is known that mineral oil used on its own is not always as effective for protection against PVM as it is in the case of PVY (Wróbel 2006, 2007, 2011a, 2012). In many cases effectiveness of protection depends on the year of research and thus also on the infectious pressure of the virus, yet the results are not unequivocal. Across the literature worldwide there is no information as such examining the possibility of potato protection against PVM. From the conducted research it is not entirely clear for all of the research years, but it appears that in the case of this particular virus the mixture of mineral oil with Pirimor 500 WG is the only effective mixture (according to the statistical analysis). Other combinations that could have been singled out are Sunspray 850 oil used separately as well as in mixture with Karate Zeon 050 CS or Mospilan 20 SP. In all of these cases the effectiveness in PVM reduction was higher than in the remaining combinations, indicating small statistical differences. However, these dependencies were only detected in 2008 , in which year a higher virus pressure was observed compared to the remaining years of the research.

\section{Conclusion}

Applying mixtures of insecticides with mineral oil for protection against PVY is not always as effective as applying the oil itself. Addition of insecticide may sometimes improve the efficacy of protection however, due to high extra costs it does not always have to be economical.

Acknowledgments My special thanks go to all the technical employees of the Laboratory of Potato Seed Science in Bonin for their help and assistance and involvement during the course of the research.

Open Access This article is distributed under the terms of the Creative Commons Attribution License which permits any use, distribution, and reproduction in any medium, provided the original author(s) and the source are credited.

\section{References}

Ameline, A., A. Couty, M. Martoub, S. Sourice, and P. Giordanengo. 2010. Modification of Macrosiphum euphorbiae colonisation behaviour and reproduction on potato plants treated by mineral oil. Entomologia Experimentalis et Applicata 135: 77-84.

Asjes, C.J. 1991. Control of air-borne field spread of tulip breaking virus, lily symptom less virus and lily virus $\mathrm{X}$ in lilie by mineral oils, synthetic pyrethroids, and a nematicide in the Netherlands. Netherlands Journal of Plant Pathology 97: 129-138.

Basky, Z. 2003. Virus vector aphid activity and seed potato tuber virus infection in Hungary. Journal of Pest Science 76: 83-88.

Bell, A.C. 1989. Use of oil and pyrethroid sprays to inhibit the spread of potato virus $\mathrm{Y}^{\mathrm{N}}$ in the field. Crop Protection 8: 37-39.

Boquel, S., M. Giguère, C. Clark, U. Nanayakkara, J. Zhang, and Y. Pelletier. 2013. Effect of mineral oil on Potato virus Y acquisition by Rhopalosiphum padi. Entomologia Experimentalis et Applicata 148: $48-55$.

Boiteau, G., M. Singh, and J. Lavoie. 2009. Crop border and mineral oil sprays used in combination as physical control methods of the aphid-transmitted potato virus $\mathrm{Y}$ in potato. Pest Management Science 65: 255-259.

Bradley, R.H.E. 1963. Some ways in which a paraffin oil impedes aphid transmission of potato virus Y. Canadian Journal of Microbiology 9: 369-380.

Bradley, R.H.E., C.A. Moore, and C.C. Pond. 1966. Spread of potato virus Y curtailed by oil. Nature (Lond.) 209: 1370-1371.

Bradley, R.H.E., C.V. Wade, and F.A. Wood. 1962. Aphid transmission of potato virus Y inhibited by oils. Virology 18: 327-329.

Brunt, A., Crabtree, K., Dallwitz, M., Gibbs, A., Watson, L., Zurcher, E. 1997. Plant viruses online. Descriptions and lists from the VIDE Database. http://pvo.bio-mirror.cn/refs.htm\#suscept (accessed 17 July 2013)

Castle, S.J., and P.H. Berger. 1993. Rates of growth and increase of Myzus persicae on virus-infected potatoes according to type of virus-vector relationship. Entomologia Experimentalis et Applicata 69: 51-60.

Cerato, C., D. Rongai, S. Borgatti, and M.L. Tamba. 1994. Study of the aphid populations and virus diseases on seed potato crops. (In Italian, with English abstract) Informatore Agrario 50(48): 67-72.

Chrzanowska, M. 2004. Nasilenie w występowaniu chorób wirusowych ziemniaka. (In Polish.) Ochrona Roślin. 7/8: 25-28

Chrzanowska, M., and H. Zagórska. 1996. The reaction of Polish potato cultivars to the severe strain of Potato virus $\mathrm{M}$ after mechanical 
inoculation. (In Polish, with English abstract) Biuletyn Instytutu Ziemniaka 46: 17-27.

Chrzanowska, M., and H. Zagórska. 2004. Potato virus Y could be the cause of external and internal necrotic defects of tubers. (In Polish, with English abstract) Zeszyty Problemowe Postepów Nauk Rol 500: 367-372.

Chrzanowska, M., K. Michalak, H. Zagórska, and K. Szajko. 2011. The reaction to virus infection of potato cultivars from the Polish National List in 2010. (In Polish, with English abstract) Biuletyn IHAR 260(261): 309-324.

Collar, J.T., C. Avilla, and A. Fereres. 1997. New correlations between aphid stylet paths and nonpersistent virus transmission. Environmental Entomology 26(3): 537-544.

Derron, J.O., and G. Goy. 1990. Relative importance of alate aphids frequently encountered on potatoes as vectors of potato virus $\mathrm{Y}$ $\left(\mathrm{PVY}^{\mathrm{N}}\right.$ ), taking their mobility into account. (In French, with English abstract) Revue Suisse d'Agricultura 22(5): 277-281.

Fageria, M.S., S. Boquel, G. Leclair, and Y. Pelletier. 2014. The use of mineral oil in potato protection: dynamics in the plant and effect on potato virus Y spread. American Journal of Potato Research. doi:10. 1007/s12230-014-9377-9.

Fletcher, J.D. 2012. A virus survey of New Zealand fresh, process and seed potato crops during 2010-11. New Zealand Plant Protection 65: 197-203.

Gibson, R.W., and A.D. Rice. 1986. The combined use of mineral oils and pyrethroids to control plant viruses transmitted non- and semipersistently by Myzus persicae. The Annals of Applied Biology 109: 465-475.

Hansen, L.M., and S.L. Nielsen. 2012. Efficacy of mineral oil combined with insecticides for the control of aphid virus vectors to reduce potato virus Y infections in seed potatoes (Solanum tuberosum). Acta Agriculturae Scandinavica, Section B - Soil and Plant Science 62(2): 132-137.

Harringrton, R., E. Barlet, D.K. Riley, R.H. Ffrench-Constant, and S.J. Clark. 1989. Resurgence of insecticide-resistant Myzus persicae on potatoes treated repeatedly with cypermethrin and mineral oil. Crop Protection 8: 340-348.

Horowitz, A.R., Z. Mendelson, and I. Ishaava. 1997. Effect of abamectim mixed with mineral oil on the sweetpotato whitefly (Homeoptera: Aleyrodidae). Journal of Economic Entomology 90: 349-353.

Iovieno, P., E. Lahoz, F. Porrone, C. Biondani, A. Carella, and R. Contillo. 2002. Use of light mineral oil to reduce the severity of PVY and CMV infections on tobacco in Italy. Il Tabacco 10: 57-61.

Kerlan, C. 2009. Potato viruses. In: Mahy B.W.J. and van Regenmortel M.H.V. editors, Desk Encyclopedia of Plant and Fungal Virology. Academic Press, p. 458-471

Kostiw, M. 1987. Przenoszenie ważniejszych wirusów ziemniaka przez mszyce. (In Polish) Potato Research Bonin: pp 105

Kostiw, M. 2011. The occurrence of major potato viruses in Poland. Journal of Plant Protection Research 51: 204-209.

Kostiw, M., and B. Robak. 2002. The spread of PVY, PVM, PVS and PLRV at Bonin conditions during 1996-1999. Journal of Plant Protection Research 42(2): 165-171.

Kostiw, M., and B. Robak. 2008. Species composition, migration period and dynamics of number of non potato colonizing aphids in different regions of Poland. (In Polish, with English abstract) Progress in Plant Protection 48(3): 881-888.

Kostiw, M., and B. Robak. 2010. Infection pressure of PVY, PVM, PVS and PLRV in the period 2006-2008 in Bonin. (In Polish, with English abstract) Biuletyn IHAR 256: 141-151.

Kostiw, M., and T. Iskrzycka. 1976. Possibility of limitation of the non persistant potato viruses spread by the spraying of plants with oil substances. (In Polish, with English abstract) Biuletyn Instytutu Ziemniaka 18: 59-64.

Kurppa, A., and A. Hassai. 1989. Reaction of four table potato cultivars to primary and secondary infection by potato viruses $\mathrm{Y}^{0}$ and $\mathrm{Y}^{\mathrm{N}}$. Annales Agriculturae Fenniae 28(4): 297-307.
Loebenstein, G., and G. Thottappilly. 2003. Virus and virus-like diseases of major crops in developing countries, 800. Dordrecht: Kluwer Academic Publishers.

Lowery, D.T., M.K. Sears, and C.S. Harmer. 1990. Control of turnip mosaic virus of rutabaga with applications of oil, whitewash and insecticides. Journal of Economic Entomology 83: 23522356.

Marco, S. 1993. Incidence of non-persistently transmitted viruses in pepper sprayed with whitewash, oil and insecticide, alone or combined. Plant Disease 77: 1119-1122.

Martín-López, B., I. Varela, S. Marnotes, and C. Cabaleiro. 2006. Use of oils combined with low doses of insecticide for the control of Myzus persicae and PVY epidemics. Pest Management Science 62(4): 372 378.

Martoub, M., A. Couty, P. Giordanengo, and A. Ameline. 2010. Opposite effects of different mineral oil treatments on Macrosiphum euphorbiae survival and fecundity. Journal of Pest Science 84(2): 229-233.

Milošević, D. 1996. Efficacy of oil and insecticides in potato plant protection against infection by potato virus $\mathrm{Y}$ and leaf roll virus (PVY and PLRV). Plant Protection 47(4): 333-342.

Milošević, D., S. Stemenković, and P. Perić. 2012. Potential use of insecticides and mineral oil for the control of transmission of major aphid-transmitted potato viruses. Pesticides and Phytomedicine 27(2): 97-106.

Moustafa, O.K., and Z.M. El-Attal. 1985. Enhancement of the efficiency of some insecticides against thrips and cotton leafworm by mineral oils. The Journal of Agricultural Science 105: 63-66.

Olubayo, F., A. Kibaru, J. Nderitu, R. Njeru, and M. Kasina. 2010. Management of aphids and their vectored diseases on seed potatoes in Kenya using synthetic insecticides, mineral oil and plant extract. Journal of Innovation Development Strategy 4(2): 1-5.

Powell, G., Hardie, J., 1994. Effects of mineral oil applications on aphid behaviour and transmission of potato virus Y. Brighton Crop Protection Conference - Pest and Diseases Vol.1: 229-234

Powell, G., J. Hardie, and J.A. Pickett. 1998. The effects of antifeedant compounds and mineral oil on stylet penetration and transmission of potato virus Y by Myzus persicae (Sulz.) (Hom., Aphididae). Journal of Applied Entomology 122: 331-333.

Pree, D.J., A.R. Stevenson, and E.S. Barszcz. 1996. Toxicity of pyrethroid insecticides to carrot weevils: enhancement by synergists and oils. Journal of Economic Entomology 89: 1254-1261.

Rahman, M.S., A.M. Akanda, I.H. Mian, M.K.A. Bhuian, and M.R. Karim. 2010. Growth and yield performance of different generations of seed potato as affected by PVY and PLRV. Bangladesh Journal of Agricultural Research 35: 37-50.

Rahman, M.S., and A.M. Akanda. 2010. Effect of PLRV infected seed tuber on disease incidence, plant growth and yield parameters of potato. Bangladesh Journal of Agricultural Research 35: 359-366.

Robert, Y. 1971. Epidémiologie de l'enroulement de la pomme de terre: capacité vectrice de stades et de formes des pucerons Aulacorthum solani Kltb., Macrosiphum euphorbiae et Myzus persicae Sulz. (In French). Potato Research 14: 130-139.

Robert, Y., and Y. Maury. 1970. Capacités vectrices comparées de plusieurs souches de Myzus persicae Sulz., Aulacorthum solani Kltb. et Macrosiphum euphorbiae Thomas dans l'étude de la transmission de l'enroulement de la pomme de terre. (In French). Potato Research 13: 199-209.

Rolot, J.L., Seutin, H., Deveux, L. 2008. Effectiveness of paraffinic mineral oil, insecticides and vegetal oil to control Potato virus $Y$ (PVY) spread in potato seeds multiplication fields. Abstracts. 17th Triennial Conference of the European Association for Potato Research, July 6-10, Braşov, România: 111-118

Sharma, P.D. 2006. Plant Pathology. Alpha Science International, Oxford: 550p 
Shukla, D.D., C.W. Ward, and A.A. Brunt. 1994. The potyviridae, 516. Cambridge: Cambridge University Press.

Sigvald, R. 1984. The relative efficiency of some aphid species as vectors of potato virus $\mathrm{Y}^{0}\left(\mathrm{PVY}^{0}\right)$. Potato Research 27(3): 285-290.

Sigvald, R., Hulle, M. 2004. Aphid-vector management in seed potatoes: monitoring and forecasting. EAPR Virology 2004, Abstracts. 12th European Association for Potato Research Virology Section Meeting, 13-19 June, Rennes, France: 8-11

Solomon-Blackburn, R.M., and H. Barker. 2001. Breeding virus resistant potatoes (Solanum tuberosum): a review of traditional and molecular approaches. Heredity 86: 17-35.

StatSoft, inc. 2011. Statistica (data analysis system), version 10, http:// www.statsoft.pl

Steinger, T., H. Gilliand, and T. Hebeisen. 2014. Epidemiological analysis of risk factors for the spread of potato viruses in Switzerland. The Annals of Applied Biology 164: 200-207.

Thomas, P.E., and S. Hassan. 2002. First report of twenty-two new hosts of Potato leafroll virus. Plant Disease 86: 561.

Treacy, M.F., J.H. Benedict, K.M. Schmidt, and R.M. Anderson. 1991. Mineral oil: enhancement of field efficacy of a pyrethroid insecticide against the boll weevil (Coleoptera: Curculionidae). Journal of Economic Entomology 84: 659-663.

Turska, E. 1984. Limiting of potato tuber infection by non-persistent viruses by plant spraying with mineral oils. Zeszyty Problemowe Postepów Nauk Rolniczych 310: 99-110.

Turska, E., and S. Wróbel. 1999. The limitation of PVY spreading in potato by application of oil Sunspray 11 E. (In Polish, with English abstract) Progress in Plant Protection 39(2): 841-844.

van Toor, R.F., G.M. Drayton, R.A. Lister, and D.A.J. Teulon. 2009. Targeted insecticide regimes perform as well as a calendar regime for control of aphids that vector viruses in seed potatoes in New Zealand. Crop Protection 28: 599-607.

Weeb, S.E., and B.L. Stephen. 1993. Effect of oil and insecticide on epidemics of potyviruses in watermelon in Florida. Plant Disease 77: 869-874.

Whitworth, J.L., P. Nolte, C. McIntosh, and R. Davidson. 2006. Effect of Potato virus $\mathrm{Y}$ on yield of three potato cultivars grown under different nitrogen levels. Plant Disease 90(1): 73-76.
Wisłocka, M., Gabriel, W. 1980. Wpływ odległości od źródeł infekcji na ograniczenie porażenia wirusami przy pomocy insektycydów. (In Polish). Abstracts. XIV Sesja Naukowa - Nasiennictwo Ziemniaka, 5-6 March, Koszalin, Poland: 73-74

Wójcik, A.R., W. Gabriel, and W. Woźnica. 1976. Methods of transformation of percentagewise infection data in epidemiology of potato viruses. (In Polish, with English abstract) Biuletyn Instytut Ziemniaka 17: 83-100.

Wróbel, S. 2006. The role of mineral oil in potato protection against aphids and viruses infection. (In Polish, with English abstract) Acta Scientiarum Polonorum Agricultura 5(1): 83-92.

Wróbel, S. 2007. Effect of a mineral oil on Muzus persicae capability to spread of PVY and PVM to successive potato plants. Journal of Plant Protection Research 47(4): 383-390.

Wróbel, S. 2011a. Adjuvants in seed potato protection against PVY and PVM infection. (In Polish, with English abstract) Biuletyn IHAR 259: 251-262.

Wróbel, S. 2011b. The influence of mineral oil and insecticide mixtures on the occurrence dynamics of aphids on potato plants. (In Polish, with English abstract) Progress in Plant Protection 51(2): 625-629.

Wróbel, S. 2012. Comparison of mineral oil and rapeseed oil used for the protection of seed potatoes against PVY and PVM infections. Potato Research 55(1): 83-96.

Wróbel, S. 2013. Modification of ELISA by replacing incubation of microtiter plates in an incubator with their shaking in PVY, PVM and PLRV detection. American Journal of Potato Research. doi:10. 1007/s12230-013-9355-7.

Wróbel, S., and A. Wąsik. 2013. Seed potato production in Poland. American Journal of Potato Research. doi:10.1007/s12230-0139346-8.

Wróbel, S., and E. Turska. 2007. Influence of localisation of virus infections sources in natural conditions in spread PVY and PLRV. (In Polish, with English abstract). Progress in Plant Protection 47(2): 371-374.

Zagórska, H., and M. Chrzanowska. 2007. Analysis of the results of studies conducted in 1973-2005 on reaction of potato cultivars to Potato virus M. (In Polish, with English abstract) Biuletyn IHAR 243: 227-234. 